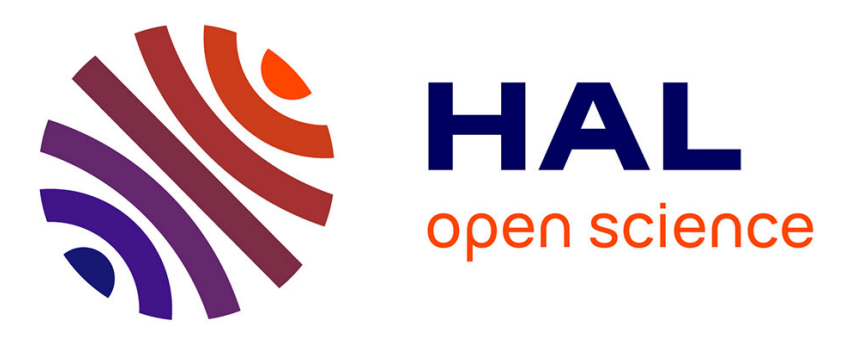

\title{
Detecting HIV-1 Tat in Cell Culture Supernatants by ELISA or Western Blot
}

Fabienne Rayne, Solène Debaisieux, Annie Tu, Christophe Chopard, Petra

Tryoen-Toth, Bruno Beaumelle

\section{- To cite this version:}

Fabienne Rayne, Solène Debaisieux, Annie Tu, Christophe Chopard, Petra Tryoen-Toth, et al.. Detecting HIV-1 Tat in Cell Culture Supernatants by ELISA or Western Blot. HIV Protocols Third edition, 1354, pp.329-342, 2016, Methods in Molecular Biology. hal-02137760

\section{HAL Id: hal-02137760 \\ https://hal.science/hal-02137760}

Submitted on 16 Nov 2020

HAL is a multi-disciplinary open access archive for the deposit and dissemination of scientific research documents, whether they are published or not. The documents may come from teaching and research institutions in France or abroad, or from public or private research centers.
L'archive ouverte pluridisciplinaire HAL, est destinée au dépôt et à la diffusion de documents scientifiques de niveau recherche, publiés ou non, émanant des établissements d'enseignement et de recherche français ou étrangers, des laboratoires publics ou privés. 


\title{
Detecting HIV-1 Tat in cell culture supernatants by ELISA or Western blot
}

\author{
Fabienne Rayne ${ }^{1}$, Solène Debaisieux ${ }^{1}$, Annie Tu$^{2}$, Christophe Chopard $^{1}$, Petra Tryoen ${ }^{2}$ and Bruno \\ Beaumelle ${ }^{1}$ \\ ${ }^{1}$ CPBS, UMR 5236 CNRS, University of Montpellier, France \\ ${ }^{2}$ Institut des Neurosciences Cellulaires et Intégratives, CNRS UPR3212, University of Strasbourg, \\ France.
}

Published in Methods Mol Biol. 2016;1354:329-42

\section{Summary}

HIV-1 Tat is efficiently secreted by HIV-1 infected or Tat-transfected cells. Accordingly, Tat concentrations in the nanomolar range have been measured in the sera of HIV-1 infected patients, and this protein acts as a viral toxin on bystander cells. Nevertheless, assaying Tat concentration in media or sera is not that straightforward because extracellular Tat is unstable and particularly sensitive to oxidation. Moreover, most anti-Tat antibodies display limited affinity. Here, we describe methods to quantify extracellular Tat using a sandwich ELISA or Western blotting when Tat is secreted by suspension or adherent cells, respectively. In both cases it is important to capture exported Tat using antibodies before any Tat oxidation occurs otherwise it will become denatured and unreactive toward antibodies.

Key words: HIV-1, Tat, secretion, ELISA, immunoblots.

Contact Mail bruno.beaumelle@irim.cnrs.fr

\section{Introduction}

HIV-1 Tat is a small (86 to 101 residues) and basic protein that enables efficient viral transcription and is required for HIV-1 multiplication [1]. The capacity of HIV-1 infected cells to secrete Tat in the absence of cell lysis was demonstrated in the 1990s [2]. We recently showed that this secretion process, although unconventional, is very efficient since most Tat is exported by infected cells [3]. Circulating Tat can be taken up by various cell types such as T-cells, macrophages, endothelial cells and neurons. Tat will then cross the endosome membrane to reach the target cell cytosol and elicit a number of cell responses [4].

We first developed a sandwich ELISA assay, so that minute concentrations of Tat can be reliably assayed in the media of suspension cells such as T-cells that are the main HIV-1 target [3]. We used Jurkat cells for most experiments. During the development of this assay, we noticed that Tat in media was extremely sensitive to oxidation. We observed that reliable quantitation of Tat in the extracellular medium required prior degassing of the medium to remove oxygen as much as possible, the addition of freshly diluted $\beta$-mercaptoethanol and the presence of immobilized anti-Tat antibodies in wells. This is why we called this assay a "cellular ELISA" because Tat-producing cells are added to wells pre-coated with the anti-Tat antibody. This enables antibodies to capture secreted Tat as soon as it is secreted by cells, before Tat would be oxidated that would render it unreactive toward antibodies. Another assay was developed for the use of adherent cells. In this case, we used Tat-FLAG transfected PC12 cells. Anti-FLAG antibodies covalently linked to agarose beads were directly added to the medium before immunoprecipitation and Western blot. For both techniques, it is necessary to assay both intracellular Tat and secreted Tat in order to calculate the secretion efficiency. 


\section{Materials}

\subsection{Tat and Cell culture}

1. Purified HIV-1 Tat can be obtained from various commercial sources or from the NIH AIDS reagent program.

2. The Jurkat cell line (clone E6-1 from ATCC) is a CD4+ T-cell line that grows in suspension.

3. PC12 cells are rat pheo-chromocytoma cells that adhere to tissue culture dishes.

4. Fetal Bovine Serum (FBS) and Horse Serum (HS) : heat inactivate the sera in a water bath at $56{ }^{\circ} \mathrm{C}$ during $30 \mathrm{~min}$ then store frozen in aliquots at $-20^{\circ} \mathrm{C}$.

5. Antibiotics: penicillin $(10,000 \mathrm{U} / \mathrm{ml})$ and streptomycin $(10 \mathrm{mg} / \mathrm{ml})$. Aliquot, store frozen at $20^{\circ} \mathrm{C}$ and dilute $100 \mathrm{x}$ in cell culture medium.

6. RPMI and DMEM basal medium (containing $4.5 \mathrm{~g} / \mathrm{L}$ of glucose).

7. RPMI supplemented with $10 \% \mathrm{FBS}$ and antibiotics (RPMI/FBS). Store this medium at $4^{\circ} \mathrm{C}$, then warm to $37^{\circ} \mathrm{C}$ before adding to cells.

8. RPMI/FBS supplemented with $20 \mu \mathrm{M} \beta$-mercaptoethanol (RPMI/FBS/BME). When indicated it should be degassed for 20-40 min using a sterile vacuum Erlenmeyer flask and a pump.

9. Complete medium for PC12 cells (RPMI supplemented with $10 \%$ heat inactivated HS and 5\% FBS). Store complete medium at $4^{\circ} \mathrm{C}$, then warm to $37^{\circ} \mathrm{C}$ before adding to cells.

10. Immunocapture medium for PC12 cells (complete medium supplemented with $20 \mu \mathrm{M} \beta$ mercaptoethanol). Prepare fresh and degas before use.

11. Trypsin-EDTA solution ( $0.25 \%$ trypsin, 1 mM EDTA in PBS with phenol red). Store at $4{ }^{\circ} \mathrm{C}$ after thawing.

12. A poly-L-lysine (PLL) solution can be used for PC12 cell plating before transfection. Use PLL of 70, $000-150,000 \mathrm{MW}$ to prepare a $10 \mathrm{x}$ PLL stock solution (100 $\mu \mathrm{g}$ PLL /ml of water) that should be stored in aliquots at $-20^{\circ} \mathrm{C}$.

13. To isolate primary $\mathrm{CD} 4^{+} \mathrm{T}$-cells: Ficoll-Hypaque, a CD4 ${ }^{+} \mathrm{T}$-cells isolation kit, phytohemaglutinnin $(1 \mathrm{mg} / \mathrm{ml})$ and interleukin-2.

14. For HIV-1 infection use NL4.3 virus.

\subsection{Transfection.}

1. The use of endotoxin-free plasmids is recommended.

2. Electroporation is the method of choice to transfect T-cells. Kits are available commercially.

3. Electroporator

4. Lipofectamine 2000 and reduced-serum Opti-MEM medium are used to transfect PC 12 cells.

\subsection{Immunoassays}

1. ELISA 96-well plates.

2. Anti-FLAG antibodies and anti-FLAG affinity gel agarose beads.

3. Anti-Tat antibodies. Sensitivity is dependent on the antibody pair used for the assay. A number of companies provide good anti-Tat antibodies. For the monoclonal anti-Tat, we noticed that those directed toward the first N- terminal residues, such as sc-65912 and sc65913 (Santa Cruz Biotechnologies) or 1D9 form AIDS Research and Reference Reagent Program (NIH) are often the best ones. Rabbit anti-Tat antibodies can be obtained from this reagent program.

4. Peroxidase-conjugated anti-rabbit antibodies.

5. Sodium carbonate buffer (0.1M, pH 9.6). Filter on $0.22 \mu \mathrm{m}$. Prepare just before use.

6. PBS/milk (PBS containing $8 \%$ powdered skimmed milk, see Note 1). 
7. PBS/Tween (PBS containing $0.05 \%$ Tween-20).

8. PBS/BME (PBS containing $20 \mu \mathrm{M} \beta$-mercaptoethanol). Degas before use.

9. Citrate buffer ( $150 \mathrm{mM} \mathrm{NaCl}, 30 \mathrm{mM}$ citrate, $20 \mathrm{mM}$ phosphate, $\mathrm{pH}$ 7.2).

10. Lysis buffer ( $150 \mathrm{mM} \mathrm{NaCl}, 10 \%$ glycerol, $1 \%$ Triton X-100, $20 \mathrm{mM}$ Tris-HCl pH 7.5). Aliquots in $1.5 \mathrm{ml}$ Eppendorf tubes and store them at $-20^{\circ} \mathrm{C}$. Just before use, add $1 \mathrm{mM}$ PMSF (from a $100 \mathrm{mM}$ stock solution in isopropanol) and a protease inhibitor cocktail.

11. 3,3',5,5' Tetramethylbenzidine (TMB)

12. $0.5 \mathrm{M} \mathrm{H}_{2} \mathrm{SO}_{4}$

13. A 96-well plate $\mathrm{OD}_{450}$ reader is needed.

\subsection{Luciferase assays.}

1. White 96-well plates.

2. Luciferase Assay Reagent (LAR).

3. A 96-well plate luminometer.

\subsection{Western blot (PC12 cells)}

1. 4-20\% acrylamide gradient gels (available commercially).

2. SDS-PAGE running buffer (192 mM Glycine, $0.1 \%$ SDS, Tris - HCl, $\mathrm{pH}$ 8.3). Prepared as a $10 \mathrm{x}$ stock solution.

3. SDS/PAGE 5x Reducing Sample Buffer (10\% SDS, 10mM dithiothreitol, 20\% glycerol, $0.05 \%$ bromophenol blue, $0.2 \mathrm{M}$ Tris-HCl, $\mathrm{pH} 6.8$ ).

4. Nitrocellulose membrane.

5. Wet transfer apparatus

6. Western blot transfer buffer: (192 mM Glycine, $0.1 \%$ SDS, Tris - $\mathrm{HCl}, \mathrm{pH} 8.3$ and $20 \%$ methanol).

7. Tris buffered saline (TBS; $0.15 \mathrm{M} \mathrm{NaCl}, 10 \mathrm{mM}$ Tris- $\mathrm{HCl}, \mathrm{pH}$ 8.0)

8. TBST (TBS containing $0.1 \%$ Tween-20).

9. Blocking solution: $3 \%$ BSA in TBST.

10. Chemiluminescent Peroxidase Substrate.

11. Chemiluminescent Imaging System (or films).

\section{Methods}

1. Jurkat cells are grown at $37{ }^{\circ} \mathrm{C}$ in the presence of $5 \%$ of $\mathrm{CO}_{2}$ and $95 \%$ humidity (i.e. in a cell culture incubator). It is cultured in RPMI/FBS. Cell density should not exceed $1.5 \times 10^{6} / \mathrm{ml}$ and dilutions are obtained by adding fresh medium.

2. PC12 cells are cultured in complete medium. Cells are maintained in 10-cm diameter Petri dishes containing $10 \mathrm{ml}$ of culture medium. PC12 cells are adherent cells and have no contact inhibition. Confluent cells should be passed by trypsinization at least once a week and be diluted 40-fold. To this end the cell monolayer is washed with PBS before adding $2 \mathrm{ml}$ of trypsin/EDTA solution (see Note 2) and incubating at $37^{\circ} \mathrm{C}$ until the cells detach (see Note 3). After incubation, stop the enzymatic reaction by adding $8 \mathrm{ml}$ of culture medium. Flush 3-4 times back and forth the cell suspension using a plastic pipette to obtain a homogenous cell suspension. Centrifuge at $1000 \mathrm{rpm}(\sim 300 \mathrm{~g})$ for $5 \mathrm{~min}$. The cell pellet is resuspended in complete medium by pipetting several times before counting (see Note 4). Cells are then transferred to a new tissue culture flask or plate (see Note 5). Use 1.5 million cells in $5 \mathrm{ml}$ of culture medium / 6-cm diameter Petri dish. Incubate cells overnight before transfection.

3. To prepare CD4+ human primary T-cells, human blood from healthy volunteers should be obtained from the local blood bank following the local laws and regulations. Isolate peripheral 
blood mononuclear cells (PBMCs) using Ficoll-Hypaque gradients following the manufacturer instructions. Resuspend PBMCs in RPMI/FBS at 1-4 x $10^{6}$ cells $/ \mathrm{ml}$. Leave them for 2- $4 \mathrm{~h}$ in tissue culture flasks to allow monocyte adherence to the flask. Non-adherent cells are peripheral blood lymphocytes (PBLs). Centrifuge PBLs (5 min x $1000 \mathrm{rpm}$ ) and isolate $\mathrm{CD} 4^{+} \mathrm{T}$-cells using the protocol provided by the kit manufacturer. Resuspend $\mathrm{CD} 4^{+} \mathrm{T}$ cells at $1-2 \times 10^{6}$ cells $/ \mathrm{ml}$ and activate them using phytohemagglutinin $(1 \mu \mathrm{g} / \mathrm{ml})$ for $24 \mathrm{~h}$. Centrifuge $\mathrm{CD}^{+}{ }^{+} \mathrm{T}$-cells, resuspend them at $1-2.10^{6}$ cells $/ \mathrm{ml}$ then add interleukin-2 $(50 \mathrm{U} / \mathrm{ml})$ for 5-6 days.

\subsection{ELISA procedure for T-cells. Day 0.}

\subsubsection{Transfection of Jurkat cells}

1. Wash cells $2 \times(1000 \mathrm{rpm} \times 5 \mathrm{~min}$ in a table top centrifuge) with RPMI (without serum and antibiotic).

2. Resuspend cells at $13 \times 10^{6}$ cells/ $\mathrm{ml}$ in RPMI.

3. Transfer $0.7 \mathrm{ml}\left(9 \times 10^{6}\right.$ cells) to a standard $4 \mathrm{~mm}$ electroporation cuvette.

4. Dilute endotoxin-free plasmids in a maximum of $30 \mu \mathrm{l}$ of water. We routinely used $20 \mu \mathrm{g} /$ transfection with 18 and $2 \mu \mathrm{g}$ of Tat and luciferase vector, respectively. An empty vector without Tat should be used for control cells. Mix gently without making bubbles.

5. Place the cuvette in the cuvette holder and electroporate (using an exponential decay pulse) at $270 \mathrm{~V}, 1000 \mu \mathrm{F}$, infinite resistance value. The pulse length should be $<25 \mathrm{msec}$. Above this value, cell viability drops dramatically.

6. Transfer cells to a $25 \mathrm{~cm}^{2}$ tissue culture flask containing $10 \mathrm{ml}$ of RPMI/FBS/BME at $37^{\circ} \mathrm{C}$.

7. Cultivate cells overnight at $37^{\circ} \mathrm{C}, 5 \% \mathrm{CO}_{2}$.

\subsubsection{Transfection of primary T-cells}

1. Transfect cells using a kit for activated T-cells and following the manufacturer's instructions.

2. Cultivate cells overnight at $37^{\circ} \mathrm{C}, 5 \% \mathrm{CO}_{2}$ in RPMI/FBS/BME.

\subsubsection{T-cell infection}

Infect purified CD4+ T-cells overnight with HIV-1 (NL4.3) using an MOI >0.5. Jurkat cells can also be used.

\subsubsection{Day 2}

1. Wash T-cells $3 \mathrm{x}$ with RPMI/FBS/BME, count and dilute cells to $0.5 \mathrm{x} 10^{6} / \mathrm{ml}$ (Jurkats) or $1 \mathrm{x}$ $10^{6} \% \mathrm{ml}$ (primary CD4 ${ }^{+} \mathrm{T}$-cells).

2. Prepare the ELISA plates: two plates are needed. The first one will be used for the secretion assay that will capture secreted Tat and the second one to assay intracellular Tat to normalize secretion data.

3. Dilute anti-Tat monoclonal antibody (1/2000 is a good starting point) in sodium carbonate buffer.

4. Add $100 \mu \mathrm{l} /$ well of the diluted antibody.

5. Leave overnight at $4{ }^{\circ} \mathrm{C}$.

6. Wash wells $2 \mathrm{x}$ with $200 \mu \mathrm{l}$ PBS.

7. Saturate wells for $1.5 \mathrm{~h}$ with $\mathrm{PBS} / \mathrm{milk}$

8. Wash wells $3 \mathrm{x}$ with $200 \mu \mathrm{l} \mathrm{PBS}$, leaving wells in the last wash to prevent drying. 


\subsubsection{Preparing the secretion ELISA plate (Day 3)}

1. Prepare Tat standards. Purified, endotoxin-free HIV-1 Tat should be stored at $-80^{\circ} \mathrm{C}$ using a concentration $>100 \mu \mathrm{M}(\sim 1 \mu \mathrm{g} / \mu \mathrm{l})$ in citrate buffer.

2. Prepare serial dilutions of Tat ranging from $1 \mu \mathrm{g} / \mathrm{ml}$ to $0.1 \mathrm{ng} / \mathrm{ml}$ in degassed RPMI/FBS/BME.

3. Fill the outside wells of the plate with $200 \mu$ l of degassed RPMI/FBS/BME. Important: these wells should not be used for the experiment because final readings are less reproducible in outside wells.

4. Add $100 \mu \mathrm{l}$ of Tat dilutions to the inside wells.

\subsubsection{Cell preparation (Day 3)}

1. Centrifuge cells and resuspend them at $3.75 \times 10^{6} / \mathrm{ml}$ (Jurkats) or $5 \times 10^{6} / \mathrm{ml}$ (primary CD4 ${ }^{+} \mathrm{T}$ cells) in degassed RPMI/FBS/BME, before adding $0.2 \mathrm{ml} /$ well (make triplicates).

2. Wells with untransfected or uninfected cells should be used as negative controls.

\subsubsection{Harvesting the secretion ELISA plate (Day 3)}

1. After $6 \mathrm{~h}$ at $37^{\circ} \mathrm{C}$ (see Note 6), the plate is removed from the incubator.

2. Transfer cells to $1.5 \mathrm{ml}$ centrifuge tubes, and wash wells with $0.2 \mathrm{ml}$ PBS to recover all cells.

3. Centrifuge cells $250 \mathrm{~g} \mathrm{x} 2 \mathrm{~min}$ at RT.

4. Keep $70 \mu \mathrm{l}$ of the supernatant, to be stored frozen for luciferase assay later.

5. Wash cells by adding $0.2 \mathrm{ml} \mathrm{PBS}$ at RT. Centrifuge $250 \mathrm{~g} \times 2 \mathrm{~min}$ at RT.

6. Resuspend the cell pellet in $24 \mu \mathrm{l}$ of lysis buffer. Leave for $15 \mathrm{~min}$ at RT on an orbital shaker, then place on ice.

7. In the meanwhile wash the ELISA plate $4 \mathrm{x}$ with $0.2 \mathrm{ml}$ PBS.

8. Wash the plate with PBS/Tween.

9. Add $100 \mu \mathrm{l} /$ well of rabbit anti-Tat antibody $1 / 2000$ in PBS/milk.

10. Leave the plate overnight at $4^{\circ} \mathrm{C}$.

\subsubsection{Preparing the Intracellular ELISA plate (Day 3)}

1. Dilute $6 \mu 1$ of cell lysate into $194 \mu \mathrm{l}$ of PBS/BME. Add to inside wells.

2. Prepare serial Tat dilutions ranging from $1 \mu \mathrm{g} / \mathrm{ml}$ to $0.1 \mathrm{ng} / \mathrm{ml}$ in degassed PBS/BME supplemented with $6 \mu \mathrm{L}$ lysis buffer and $194 \mu \mathrm{l}$ PBS/BME. Add to inside wells.

3. Agitate on an orbital shaker for $2-5 \mathrm{~min}$ at RT.

4. Leave at $4^{\circ} \mathrm{C}$ overnight.

\subsubsection{Processing the Intracellular ELISA plate (Day 4)}

1. Wash wells $5 \mathrm{x}$ with $200 \mu \mathrm{l}$ PBS at RT.

2. Wash the plate with PBS/Tween.

3. Add $100 \mu \mathrm{l} /$ well of rabbit anti-Tat antibody $1 / 2000$ in PBS/milk.

4. Agitate on an orbital shaker for $1 \mathrm{~h}$ at RT.

\subsubsection{Final ELISA steps (Day 4)}

1. Wash both secretion and intracellular ELISA plates $5 \mathrm{x}$ with $200 \mu \mathrm{l} \mathrm{PBS}$ at RT.

2. Add $100 \mu \mathrm{l}$ / well of peroxidase-conjugated anti-rabbit IgG 1/2000 in PBS/ milk.

3. Agitate on an orbital shaker for $1 \mathrm{~h}$ at RT.

4. Wash the plates $5 \mathrm{x}$ with PBS/Tween.

5. Add $100 \mu \mathrm{l} \mathrm{TMB} /$ well. 
6. Place the plates back on the orbital shaker under strong agitation until a blue colour appears in the key wells of the plates. It takes from $10 \mathrm{~min}$ (most often) to $1 \mathrm{~h}$ (very weak signal).

7. Stop the reaction by adding $50 \mu 1$ of $0.5 \mathrm{M} \mathrm{H}_{2} \mathrm{SO}_{4}$ / well.

8. Read the optical density at $450 \mathrm{~nm}$ using a plate reader.

\subsubsection{Luciferase Assay}

1. Use a white 96-well plate.

2. To assay luciferase activity in cell lysates, add $6 \mu$ of lysate to $30 \mu 1$ of LAR/well.

3. To assay luciferase activity in media, add $20 \mu \mathrm{l}$ of medium to $100 \mu \mathrm{l}$ of LAR /well.

4. Typical settings for the luminometer are delay $2 \mathrm{~s}$ and measure $10 \mathrm{~s}$.

\subsubsection{Calculations of secretion efficiency (Jurkat cells)}

$\mathrm{S}$ being the amount of secreted Tat (in ng), and I the amount of intracellular Tat (in ng), the secretion efficiency (\%) is $\mathrm{S} \times 100 /(\mathrm{S}+\mathrm{I})$ the error on this ratio being $100 \times(\mathrm{I} \Delta \mathrm{S}+\mathrm{S} \Delta \mathrm{I}) /$ $(\mathrm{S}+\mathrm{I})^{2}$ with $\Delta \mathrm{S}$ and $\Delta \mathrm{I}$ being the SEM of $\mathrm{S}$ and I, respectively (see Note 7). Luciferase secretion efficiency is calculated using the same procedure except that relative light units (RLU) are used instead of ng (see Note 8). For ELISA troubleshooting, see Note 9.

The experimental flow chart (Fig.1) summarizes the cellular ELISA procedure used to assay Tat secretion by T-cells.

\subsection{Western blot procedure for adherent cells}

\subsubsection{Transfection of $\mathrm{PC12}$ cells.}

1. Because most anti-Tat antibodies are poorly effective for immunoprecipitation, we use TatFLAG and thus transfect cells with Tat-FLAG instead of Tat. Control experiments performed in Jurkat cells showed that this carboxyl-terminal tag does not affect Tat secretion efficiency. This tag also enables one to use commercially available anti-FLAG gel beads that allow one to capture Tat-FLAG in solution before it becomes oxidized and thus unreactive to antibodies. Tat is quantified using anti-FLAG Western blotting.

2. One hour before cell transfection, change the PC12 culture medium to $5 \mathrm{ml}$ of Opti-MEM. Return cells to the cell culture incubator for $1 \mathrm{~h}$.

3. During the incubation period prepare the mix of plasmids with Lipofectamine 2000: $\operatorname{mix} 9 \mu \mathrm{g}$ of Tat-FLAG (or empty vector) in a volume of $500 \mu \mathrm{l}$ of Opti-MEM. Vortex briefly. In a separate tube, dilute $18 \mu \mathrm{l}$ of Lipofectamine 2000 in $500 \mu \mathrm{l}$ of Opti-MEM. Vortex briefly, then add the diluted DNA to the diluted Lipofectamine 2000. Incubate the DNA-Lipofectamine mix for $20 \mathrm{~min}$ at room temperature (RT) to allow complex formation.

4. Add the mix drop by drop to the cell culture medium. Gently agitate the culture dish back and forth to homogenously distribute the complexes. Incubate for $4 \mathrm{~h}$ in the cell culture incubator. After $4 \mathrm{~h}$, replace the transfection medium with $5 \mathrm{ml}$ of culture medium and incubate the cells overnight.

\subsubsection{Tat-FLAG immunocapture}

1. Gently rinse the cell cultures with warm DMEM and add $2 \mathrm{ml}$ of immunocapture medium / 6$\mathrm{cm}$ diameter Petri dish.

2. Prepare the anti-FLAG affinity agarose beads for immunocapture: add a $20 \mu \mathrm{l}$ aliquot of AntiFLAG affinity gel / dish to $1 \mathrm{ml}$ of DMEM in an Eppendorf tube.

3. Centrifuge the tube at $200 \mathrm{~g}$ for $1 \mathrm{~min}$. Discard the supernatant. Repeat this step $3 \mathrm{x}$ to remove all traces of glycerol from the bead-suspension.

4. Resuspend the gel in $500 \mu \mathrm{l}$ of immunocapture medium. 
5. Add this suspension drop by drop to PC12 cells expressing Tat-FLAG and previously covered with $2 \mathrm{ml}$ of immunocapture medium. Gently agitate the dish. Incubate for 4-6 h in the cell culture incubator.

6. After the incubation, shake the culture dish gently by making very slow rotations. It is best to use an inverted microscope to check that the movement does not lead to cell detachment.

Harvest the immunocapture medium and transfer it to a $15 \mathrm{ml}$ tube. Place cells on ice for lysis (see steps $11-12$ ).

7. Centrifuge the tube at $200 \mathrm{~g}$ for $1 \mathrm{~min}$ at $4^{\circ} \mathrm{C}$ to recover the beads. Discard the supernatant and resuspend beads in $1 \mathrm{ml}$ PBS.

8. Centrifuge at $200 \mathrm{~g}$ for $1 \mathrm{~min}$. Repeat this washing step $3 \mathrm{x}$.

9. After the last centrifugation step, add $20 \mu 1$ of lysis buffer and $5 \mu 1$ of $5 \times$ Reducing Sample Buffer to the beads. Freeze the samples at $-20^{\circ} \mathrm{C}$.

10. Rinse the cells carefully with $4 \mathrm{ml}$ of medium. Gently rotate the dish, then discard the medium. Repeat the washing once, keeping the cells on ice.

11. Place the dish on ice and add $1 \mathrm{ml}$ of ice-cold lysis buffer / dish. Scrape the cells thoroughly and transfer the cell lysate into an Eppendorf tube. Vortex at top speed for $10 \mathrm{~s}$ then place the tube on ice.

12. Take a $15 \mu$ laliquot of anti-Flag Affinity Gel agarose beads and wash them with lysis buffer (see steps 2-3). Resuspend beads in $100 \mu \mathrm{l}$ of lysis buffer and add them to the cell lysate. Mix gently without vortexing.

13. Place the tube on a rotating wheel for $90 \mathrm{~min}$ at $4^{\circ} \mathrm{C}$ to allow Tat immunocapture.

14. Centrifuge tubes at $200 \mathrm{~g}$ for $1 \mathrm{~min}$. Wash the beads $3 \mathrm{x}$ with $1 \mathrm{ml}$ PBS.

15. Resuspend beads in $20 \mu 1$ lysis buffer and $5 \mu$ l of 5x Reducing Sample Buffer. Store the samples at $-20^{\circ} \mathrm{C}$.

\subsubsection{Western blot of immunocaptured Tat-Flag}

1. Thaw the samples prepared from the media and cell lysates. Heat them at $95{ }^{\circ} \mathrm{C}$ for $5 \mathrm{~min}$. Place them on ice for $5 \mathrm{~min}$ and centrifuge briefly $(\sim 10 \mathrm{~s}$ at $10.000 \mathrm{~g})$.

2. In parallel, prepare the electrophoresis gel for sample loading. Take out the 4-20\% gradient acrylamide gel from its plastic wrap (see Note 10), remove the comb and rinse the wells with purified water. Assemble the gel electrophoresis device, place the gel into the tank, fill up the tank with electrophoresis running buffer and load the samples on the gel.

3. Run the gel at $170 \mathrm{~V}$ for $30 \mathrm{~min}$, making sure that the dye reaches the end of the gel but does not come out of the gel. (see Note 11).

4. Transfer proteins to a nitrocellulose membrane using a conventional wet transfer apparatus for $1 \mathrm{~h}$ at $30 \mathrm{~V}$.

5. Rinse the membrane $3 \mathrm{x}$ in TBST.

6. Incubate the membrane in blocking solution for $1 \mathrm{~h}$ with shaking.

7. Incubate the membrane with rabbit anti-FLAG 1:400 in blocking solution for $1 \mathrm{~h}$ with shaking.

8. Wash the membrane $3 \mathrm{x}$ for $10 \mathrm{~min}$ in TBST.

9. Incubate the membrane with peroxidase-anti-rabbit $\operatorname{IgG}(1: 25000)$ for $1 \mathrm{~h}$.

10. Wash the membrane $4 \times$ for 10 min with TBST.

11. Incubate the membrane with the chemiluminescence substrate solution for $5 \mathrm{~min}$ at room temperature in the dark. Remove the excess of substrate solution, place the membrane between two plastic sheets and immediately capture chemiluminescence signal with a cooled CCD device (or films). Use various exposure times to obtain unsaturated signal images. Tat-FLAG is detected at $\sim 12 \mathrm{kDa}$. Dimers of Tat can also be detected $\sim 22 \mathrm{kDa}$. 
Quantify relative band intensities using a quantification software such as ImageJ. This will enable one to evaluate the amount of Tat released into the cell culture medium (S) and present intracellularly (I). Calculations are then performed as described above for T-cells (3.1.12). It is also possible to use cotransfected luciferase to monitor transfected cell lysis, essentially as detailed for T-cells.

\section{Notes.}

1.Important: use a milk package opened less than 2 months before.

2.It is also possible to use EDTA without trypsin to detach PC12 Cells. The procedure is the same.

3. To favour cell detachment, gently hit the side of the Petri dish. When all cells are detached they float in the medium and this can be easily seen with the naked eyes, or using an inverted microscope if necessary. Usually 2 min are sufficient to detach PC12 cells.

4. PC12 cells tend to form small clusters in cell suspension, hence complicating counting. A confluent $10-\mathrm{cm}$ diameter Petri dish contains $\sim 10$ millions cells.

5. If needed, it is possible to increase the adherence of PC12 cells by pretreating the Petri dish surface with a PLL solution before cell plating. To this end, add $2 \mathrm{ml}$ of sterile PLL solution to a $6 \mathrm{~cm}$ diameter Petri dish and incubate $1 \mathrm{~h}$ at $37^{\circ} \mathrm{C}$. After incubation, remove the PLL solution and use the dish directly for cell plating.

6. Incubation can be longer if the medium does not become too much acidic, i.e. yellow.

7. ELISA Calculations. It should be noted that for most anti-Tat antibody pairs (monoclonal / polyclonal), standard curves will be different for the secretion and intracellular plate (Fig.2). This is presumably due to the presence of detergent (from the lysis buffer) in the expression plate. Both standard curves are thus needed to first calculate the amount of Tat in the medium and intracellular, before calculating the secretion efficiency. Calculating directly from OD values can lead to erroneous secretion values. The extent of the error will depend on the difference between the standard curves and thus on the antibody pair.

8. Sensitivity and specificity of the ELISA assay. Fig. 3 shows that amount of secreted Tat is linear with the number of Jurkat cells present in the well, while Fig. 4 shows that luciferase release is negligible compared to Tat secretion.

9. ELISA Troubleshooting. If no signal is detected, the affinity of the antibodies should be checked by Western blotting. If high background is observed, it is possible to use a biotinylated rabbit anti-Tat detected using streptavidin-peroxidase [5].

10. Alternatively, Tat can also be efficiently separated on $15 \%$ PAGE/ Tricine gels [6].

11.Tat is a small protein $(\sim 11 \mathrm{kDa})$ that, depending on the gel system, can easily run out of the gel. 


\section{Acknowledgement}

This work was funded by the CNRS, the ANRS and Sidaction.

\section{References}

1. Ott M, Geyer M, Zhou Q (2011) The control of HIV transcription: keeping RNA polymerase II on track. Cell Host Microbe 10:426-435

2. Ensoli B, Barillari G, Salahuddin SZ, Gallo RC, Wong-Staal F (1990) Tat protein of HIV-1 stimulates growth of cells derived from Kaposi's sarcoma lesions of AIDS patients. Nature 345:8486

3. Rayne F, Debaisieux S, Yezid H, Lin YL, Mettling C, Konate K, Chazal N, Arold ST, Pugniere M, Sanchez F, Bonhoure A, Briant L, Loret E, Roy C, Beaumelle B (2010) Phosphatidylinositol-(4,5)bisphosphate enables efficient secretion of HIV-1 Tat by infected T-cells. EMBO J 29:1348-1362

4. Debaisieux S, Rayne F, Yezid H, Beaumelle B (2012) The Ins and Outs of HIV-1 Tat. Traffic 13:355-363

5. Johnson TP, Patel K, Johnson KR, Maric D, Calabresi PA, Hasbun R, Nath A (2013) Induction of IL-17 and nonclassical T-cell activation by HIV-Tat protein. Proc Natl Acad Sci U S A 110:1358813593

6. Schagger H (2006) Tricine-SDS-PAGE. Nat Protoc 1:16-22 
Figure 1 : Experimental flow chart for the cellular ELISA secretion assay (T-cells)

\section{Secretion Plate}

Cells in $200 \mu \mathrm{l} ; 6 \mathrm{~h}$ at $37^{\circ} \mathrm{C}$

Wash wells with $200 \mu$ PBS

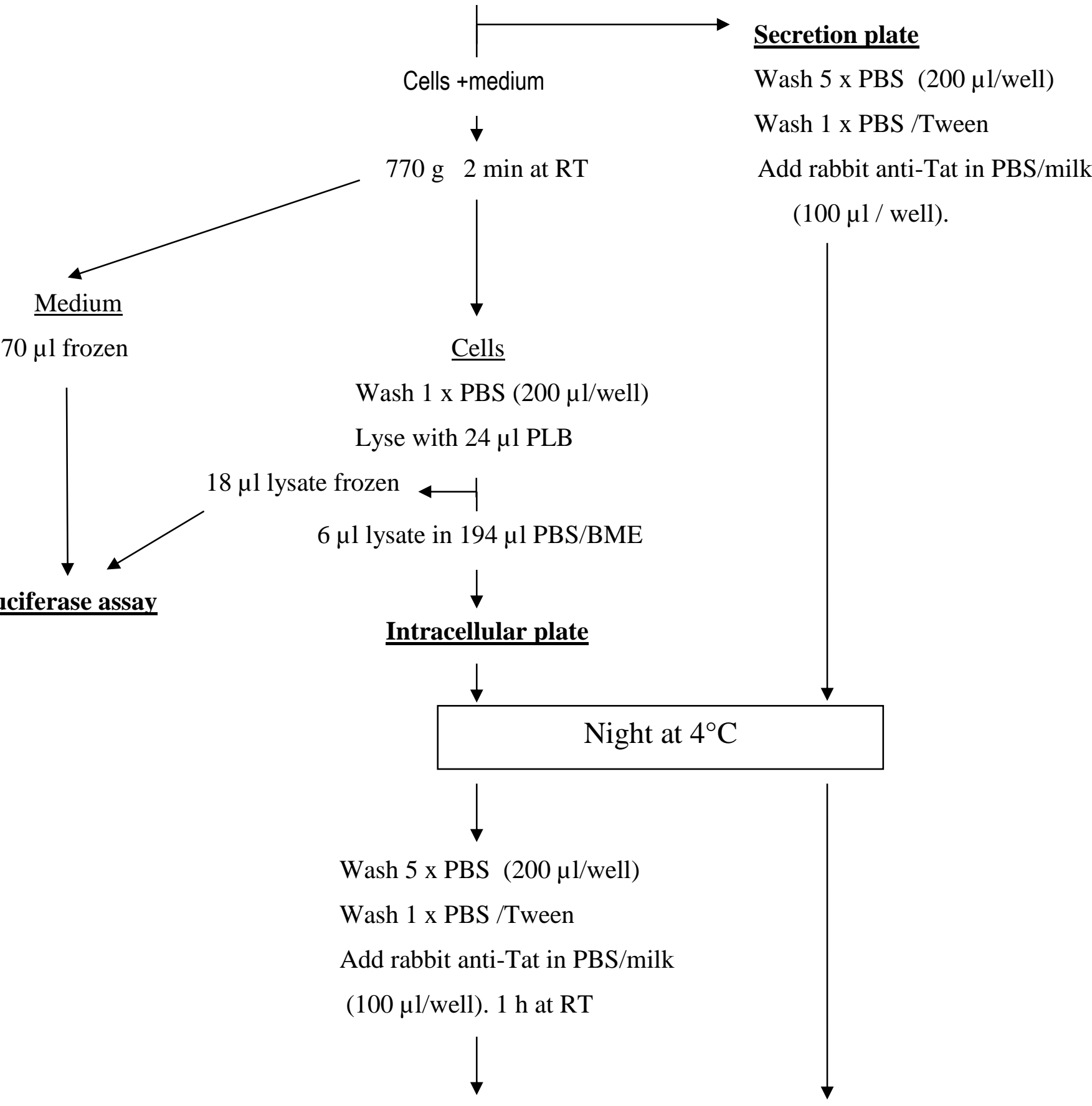

Wash 5 x PBS/ Tween $(200 \mu \mathrm{l} /$ well $)$

Add $100 \mu$ l peroxidase-anti-rabbit in PBS / milk

$1 \mathrm{~h}$ at RT

Wash 5 x PBS/ Tween $(200 \mu \mathrm{l} /$ well $)$

Develop with TMB (100 $\mu 1 /$ well $)$

Stop with $50 \mu \mathrm{l}$ of $0.5 \mathrm{M} \mathrm{H}_{2} \mathrm{SO}_{4}$

Read at $450 \mathrm{~nm}$ 


\section{Figure 2}

Standard curves.

Purified recombinant Tat was diluted in the indicated medium and assayed by ELISA. Means \pm SEM ( $n=3)$. Results from a typical experiment.

\section{Figure 3}

Secretion efficiency. Jurkat $\mathrm{T}$ cells were transfected with Tat and luciferase (Tat) or with an empty vector and luciferase (Mock). The indicated number of cells was then plated in wells of a 96-well plate $(n=4)$. After 6 $h$ at $37^{\circ} \mathrm{C}$ secreted and intracellular Tat were assayed by ELISA. Tat secretion is linearly dependent on cell number.

\section{Figure 4}

\section{Specificity of Tat secretion.} Jurkat $\mathrm{T}$ cells were transfected with Tat and luciferase (Tat), before essaying their extracellular and intracellular levels by ELISA $(n=4)$ to calculate Tat secretion efficiency as described in the text. Results from a typical experiment. Luciferase release is negligible compared to Tat secretion.
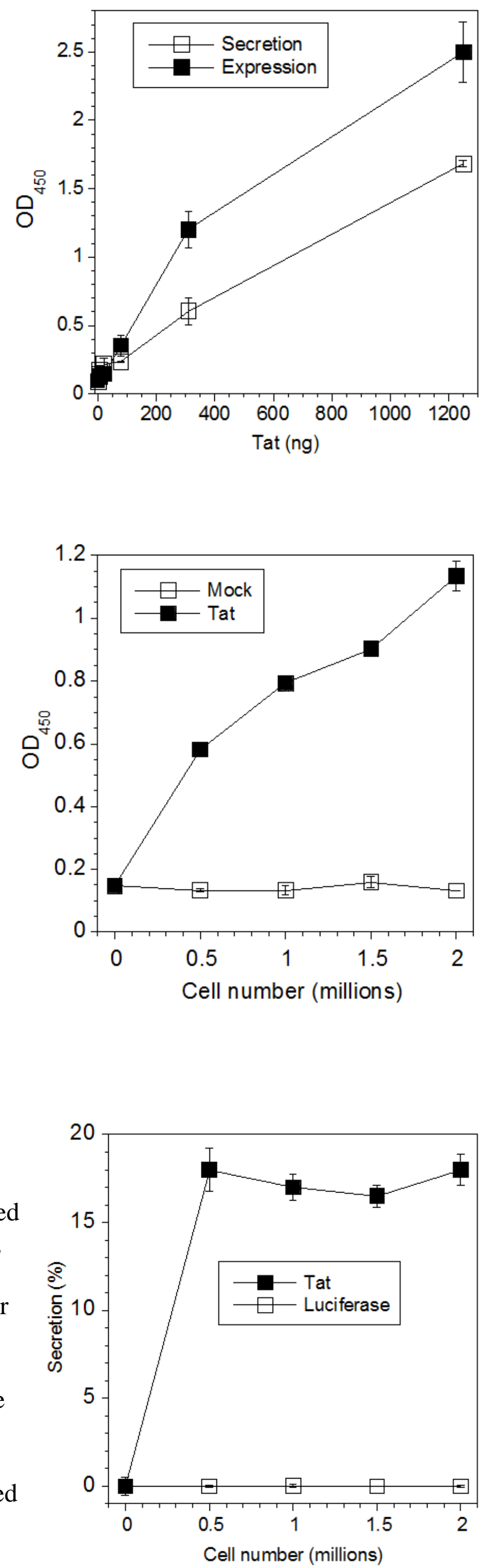